\title{
Bird composition and diversity in oak stands under variable coppice management in Northwestern Turkey
}

\author{
Vedat Beskardes ${ }^{(1)}$, \\ Akif Keten ${ }^{(2)}$, \\ Meric Kumbasli ${ }^{(3)}$, \\ Burak Pekin ${ }^{(4)}$, \\ Ersel Yilmaz ${ }^{(5)}$, \\ Ender Makineci ${ }^{(6)}$, \\ Emrah Ozdemir ${ }^{(5)}$, \\ Hayati Zengin ${ }^{(7)}$
}

\begin{abstract}
Coppice management results in profound differences in forest structure and composition, which in turn can modify habitat value for bird species. We measured bird species richness and composition at $\mathbf{5 0}$ sample plots in pure oak forest stands in northwestern Turkey, which differed in age, cover and height in association with coppice management. We recorded a total of 38 bird species and 699 individuals across all stands. Regression-based multimodel inference showed that structural features of forest stands strongly affect bird diversity and abundance. While canopy cover and tree height affect bird diversity positively, elevation of sampling plots, tree density and tree diameter at breast height (DBH) had a negative effect. In addition, constrained ordination analyses revealed that canopy cover was the most important factor influencing bird species composition. Forest stands that have $42-85 \%$ canopy cover, i.e., a few (2009-2580 oak trees) large tall $(13.36-15.78 \mathrm{~m})$ trees, were the most preferred habitat by bird species. However, we also found that different bird species favor different stand structural features. Thus, variation in stand structure from maintaining some coppice management across the landscape may be beneficial for rare or endangered species and result in greater landscape level biodiversity.
\end{abstract}

Keywords: Avian Fauna, Canopy Height, Vegetation Seral Stage, Canopy Cover, Multi-model Inference, Thrace

\section{Introduction}

Coppice management was widespread throughout European forests for centuries but was largely abandoned in the second half of the $19^{\text {th }}$ century (Mullerova et al. 2014, Srámeki et al. 2015), mostly due to the substitution of firewood with fossil fuels (Sieferle 2001) and changes in silvicultural practices (Rackham 2008). In Turkey, coppicing has been a common practice for hundreds of years (Makineci et al. 2011). However, the Turkish General Directorate of Forestry abandoned the practice in 2006, and a "close-to-nature" approach has been adopted where conversion to high forest originating from seed is promoted. This approach reflects a shift from a pure timber production objective to a more holistic objective that includes habitat conservation for wildlife (Colak \& Rotterham 2007).

Coppicing directly alters the structural features of the forest canopy such as height and cover, and influences the seral stage of the vegetation community. Because it favors vegetative regeneration, coppice management can also result in low genetic diversity of the stands (Calikoglu \&
(1) Istanbul University, Faculty of Forestry, Forest Entomology and Protection Department, Istanbul (Turkey); (2) Duzce University, Faculty of Forestry, Wildlife Ecology and Management Department, Duzce (Turkey); (3) Abant Izzet Baysal University, Faculty of Agriculture and Natural Science, Wildlife Ecology and Management Department, Bolu (Turkey); (4) Istanbul Technical University, Eurasia Institute of Earth Sciences, Istanbul 34469 (Turkey); (5) Istanbul University, Faculty of Forestry, Forest Yield and Biometry Department, Istanbul (Turkey); (6) Istanbul University, Faculty of Forestry, Soil Science and Ecology Department, Istanbul (Turkey); (7) Duzce University, Faculty of Forestry, Forest Biometry and Management Department, Duzce (Turkey)

@ Vedat Beskardes (vkardes@istanbul.edu.tr)

Received: May 09, 2017 - Accepted: Nov 13, 2017

Citation: Beskardes V, Keten A, Kumbasli M, Pekin B, Yilmaz E, Makineci E, Ozdemir E, Zengin $H$ (2018). Bird composition and diversity in oak stands under variable coppice management in Northwestern Turkey. iForest 11: 58-63. - doi: 10.3832/ifor2489-010 [online 2018-01-25]

Communicated by: Massimo Faccoli
Kavgaci 2002). Nonetheless, coppicing is still commonly used as a forest management system in southeastern Europe (Mullerova et al. 2014). In addition, there has been a renewed interest in utilizing coppicing as a tool for biomass production and nature conservation (Srámeki et al. 2015).

Being high in the food chain, birds are very sensitive to environmental change (Gregory \& Van Strien 2010). Breeding bird population density and community composition have been shown to vary with changes in coppice age (Fuller \& Henderson 1992, Fuller \& Warren 1993). Accordingly, forestry practices that alter the age and structure of forests, such as coppicing are highly relevant for bird species conservation (Mullerova et al. 2014). Bird abundance often increases with forest maturity, altitudinal position, and development (cover and height) of the shrub layer (Diaz 2006). However, each species may have a different habitat preference or ecological niche associated with cover and height of trees within forests (MacArthur \& MacArthur 1961).

Mature forests are important for many bird species, especially to cavity-nesting ones (Mei-Ling 2005). In European forests, bird species richness is generally higher in unmanaged stands than in less mature managed stands (Paillet et al. 2010). Soil fertility, the diversity of vertical structure, and breaks in the forest cover may all influence bird populations (Moss 1979). Tree composition (De Warnaffe \& Deconchat 


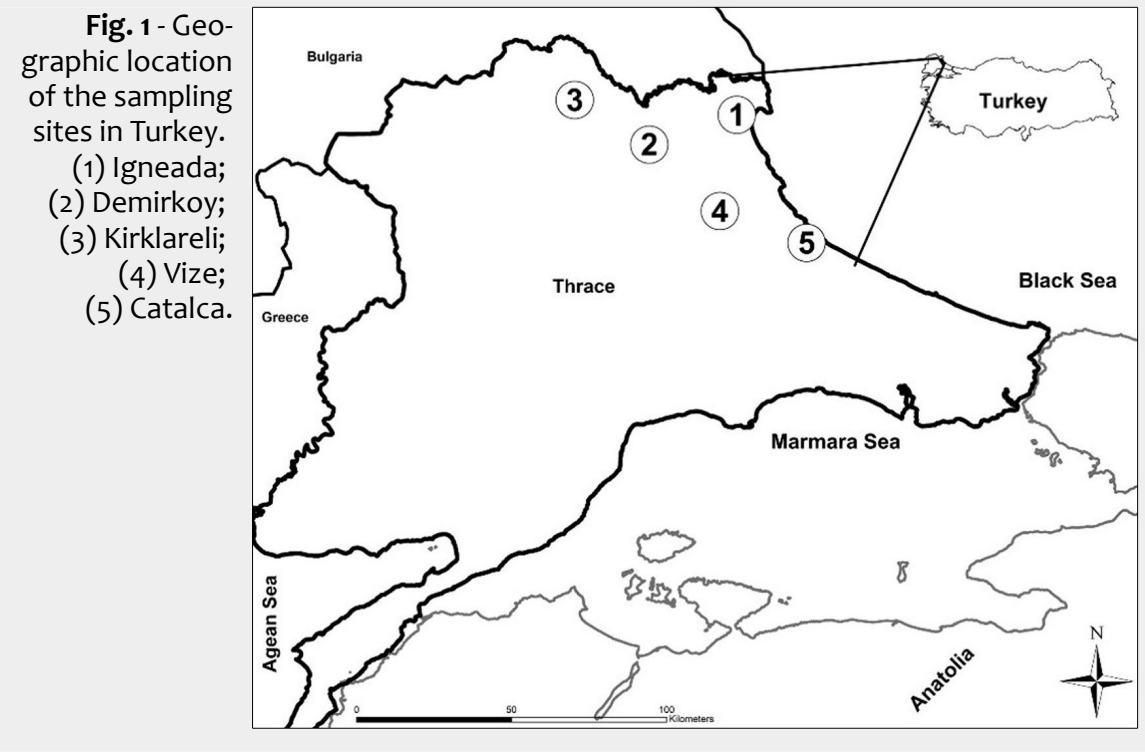

2008) and forest structure (MacArthur \& MacArthur 1961) can also strongly affect the composition and diversity of bird species in forests. However, despite harboring fewer species overall, studies have shown that young clear-cuts or small forest gaps support vastly different bird communities and may increase the regional species pool by harboring rare species (Winkler 2005). Additionally, bird-community composition changes with successional stages associated with different management regimes (Fuller \& Henderson 1992). For example, earlier stages of coppice are suitable for specialized bird species, but the requirements of other more abundant species are met more often in the old coppice (Fuller et al. 1989).

According to DeGraaf et al. (1998), forest structure has a stronger effect on bird diversity than forest cover type or stand size class. There is however little knowledge of the relationship between forest structural characteristics and wildlife abundance in Turkey. Particularly, no information is available on the responses of bird species to conversion of coppice to high oak forest and the structural stages in between. We thus sought to determine bird species richness and composition under oak stands with varying structural characteristics associated with coppice management in Thrace, a region of northwestern Turkey where oak forests and woodlands constitute a large proportion of wildlife habitat.
In doing so, we seek to better understand the role of coppicing in supporting bird conservation in the region.

\section{Material and methods}

\section{Study area}

This study was conducted on pure oak stands in northwestern Turkey, within the region of Thrace (Fig. 1). Oak species are the most commonly coppiced trees in Turkey. Forests and woodland dominated by oak cover vast areas ( 5.2 million ha) of Turkey (OGM 2014). In Thrace oaks constitute $71.7 \%$ of forest lands (around 400,000 ha Makineci et al. 2011). Over the past centuries, Thracian forests have suffered heavy destruction, and $85 \%$ of old broadleaf forests had changed to coppice forests making it difficult to come across big old oak trees (Eraslan \& Evcimen 1967). However, recent changes imposed by the Turkish Forestry Directorate favor the maintenance of a tall canopy composed of naturally regenerating trees (Colak \& Rotterham 2007).

In our study, five different sites were chosen to capture the variation in oak forests in Thrace. The selected sampling plots all represented coppice originated oak stands, with varying dominance of three major oak species: Sessile oak (Quercus petraea [Mattuschka] Liebl.), Hungarian oak (Quercus frainetto Ten.), and Turkey oak (Quercus cerris L. - Makineci et al. 2011). However,

Tab. 1 - Main climatic characteristics of sampling sites (Makineci et al. 2011).

\begin{tabular}{lcccc}
\hline Sampling Site & $\begin{array}{c}\text { Elevation } \\
(\mathbf{m} \text { a.s.I. })\end{array}$ & $\begin{array}{c}\text { Mean annual } \\
\text { precipitation } \\
(\mathbf{m m})\end{array}$ & $\begin{array}{c}\text { Average annual } \\
\text { temp. }\left({ }^{\circ} \mathrm{C}\right)\end{array}$ & $\begin{array}{c}\text { Annual water } \\
\text { deficit }(\mathrm{mm})\end{array}$ \\
\hline Igneada & 125 & 867 & 13 & 181 \\
Demirkoy & 680 & 1053 & 11 & 84 \\
Kirklareli & 500 & 550 & 14 & 274 \\
Vize & 320 & 720 & 12 & 244 \\
Catalca & 290 & 844 & 14 & 212 \\
\hline
\end{tabular}

the sites differed considerably in environmental and climatic characteristics (Makineci et al. 2011 - Tab. 1).

\section{Bird sampling}

For avifauna sampling, we selected a total of 50 plots $(100 \times 100 \mathrm{~m} ; 1 \mathrm{ha})$ with ten from each of the different sampling sites (Catalca, Demirkoy, Igneada, Kirklareli and Vize). The minimum distance among sampling plots was $1 \mathrm{~km}$. Sampling was conducted two times: late April and then early August of 2010. Bird observations were done during the morning from sunrise to 11:00 and from 15:00 to sunset. If a plot was counted in the morning in the spring, the second counting procedure for same plot was made after 15:00 in early August. In our analysis, we used total number of bird counts for each sampling plots. Each count was made by directly observing and hearing sounds of birds in 15 minutes intervals in the center of the sampling plots. In addition, we recorded habitat types, tree species, elevation and canopy cover. Observations were obtained via a single observer point count methodology (Bibby et al. 1992). The species identification was based on several field guides (Svensson et al. 2009). The bird species were categorized into guilds according to their feeding preferences as carnivore, carnivore-insectivore, granivore, granivore-frugivore, insectivore, insectivore-frugivore, insectivore-granivore, insectivore-granivore-frugivore or omnivore based on Perrins (1987) to analyze relationships between stand type and feeding guilds.

\section{Stand structure measurements}

In the past, our sample plots were managed by clear cut coppicing in 20 years rotations. However, the exact history of the rotations and the clear-cut schedules were unknown for the study sites. Accordingly, a complete inventory was taken of each stand to characterize the tree development stage (mostly July and August) in 2008, 2009, and 2010 (Makineci et al. 2011). We selected our sampling plots from these vegetation plots. Plot coordinates and elevation were determined by GPS. In each sample plot (20 × $20 \mathrm{~m}$ quadrats), we recorded tree species, measured tree density, DBH (diameter at breast height), height and cover (canopy). All data were converted to per hectare basis except cover. Cover was assessed as one of four categories: 0-10\%, 11-40\%, 41-70 and 70-100\%. Our stand structure sampling protocol is described in much greater detail in Makineci et al. (2011).

\section{Data analysis}

We calculated bird species richness as the total number of species recorded at the plots, and species diversity using the Shannon-Weaver index (Magurran 1988). Response of bird species richness and diversity to individual stand structural attributes (canopy cover, height, tree density, DBH 
and elevation etc.) were assessed using multimodel inference (Burnham \& Anderson 2002) within a mixed modeling framework (Venables \& Ripley 2002). Initially, a global model was obtained with all stand structural attributes and elevation (as covariate) which were included as fixed effects using the "Ime" and "nlme" functions of the nlme package (Pinheiro et al. 2015) within the $R$ software environment for statistical computing and graphics ( $R$ Development Core Team 2008). Site was also included in the models as a random effect to account for the five separate administrative regions our data was collected from. A log transformation was used on the response in order to meet normality when necessary and Poisson distribution was used for species richness. All of the fixed effect variables were standardized prior to analysis to allow for comparison of effect sizes among parameter estimates. Models were validated by checking the distribution of the residuals graphically to ensure a random distribution. Top models, i.e., those with a difference in AICc of no more than 4 from the best model, were determined using the "dredge" function of MuMIn package (Barton 2015) in R. Model averaging (Burnham \& Anderson 2002) was then performed using the top models with the MuMIn function "model.avg" to obtain the averaged coefficient values and relative importance of all fixed effects within the top models. Because all of the tree species in our sites were deciduous oaks, we did not expect the bird community to vary with tree species composition. Nonetheless, we initially assessed whether oak species composition was related to bird diversity and composition based on the correlation between bird species richness and diversity with the proportion of one oak species versus another graphically and statistically using Spearman's rank correlation with the "cor" function in R. If the effect was not significant, tree species composition was not considered further in the analyses.

In order to assess the association of individual species with the different stand types we performed indicator species analysis using a multi-level pattern analysis approach (De Caceres et al. 2010) using the $R$ package "indicspecies". Multi-level pattern analysis allows for the association of a species to be made to one or more groups (i.e., clusters) of sites based on both the presence and the absence of the species within the groups. This is particularly important for our study because to understand the role of woodland management in bird conservation, we need to assess the dependence of individual species to multiple forest stand types created by coppicing and logging activities. In order to achieve this, we first used cluster analysis to characterize stand types representing the variation in tree structural attributes (i.e., cover, height, density, DBH) across our study plots. K-means clustering (Hartigan \&
Wong 1979) was conducted with the $R$ base function "kmeans". The resulting stand types were then used as groupings for the species indicator analysis.

Finally, we conducted Constrained Correspondence Analysis (CCA) to assess the compositional response of the bird community to the structural attributes (i.e., cover, height, density, DBH) of our forest stands (Legendre \& Legendre 2003). In order to partial out any variation in bird composition associated with the administrative regions and elevation, we also included these factors as conditions in our CCA using the "cca" function of the vegan package (Oksanen et al. 2015) in R. The distribution of sites belonging to the different stand structural types determined from the cluster analysis was displayed on the ordination plot using the "ordiellipse" function in vegan. This multivariate approach allowed us to create an ordination that best represents the relative influence of individual stand structural attributes on the avian community as a whole.

\section{Results}

Description of sampled bird assemblage Thirty-eight bird species and 699 individuals were recorded during the survey in our sampling plots (Tab. S1 in Supplementary material). Nine feeding guilds were determined, i.e., carnivore (3 species), carnivoreinsectivore (1 species), granivore (2 species), granivore-frugivore (2 species), insectivore ( 8 species), insectivore-frugivore $(8$ species), insectivore-granivore (7 species), insectivore-granivore-frugivore (5 species), and omnivore (2 species - Tab. S1). The most observed species were Fringilla coelebs (207 birds), Parus major (80 birds) and Sitta europea (64 birds - Tab. S1).

Tab. 2 - Averaged coefficient values, estimate $(\beta)$ and standard error (SE), and relative importance (RI) of fixed effects from multiple top regression models predicting the influence of site factors on bird species richness and diversity. See Tab. S2 in Supplementary material for details on top models.

\begin{tabular}{lcccccc}
\hline \multirow{2}{*}{ Effect } & \multicolumn{2}{l}{ Richness } & \multicolumn{5}{c}{ Diversity } \\
\cline { 2 - 7 } & Est. $\boldsymbol{\beta}$ & SE & RI & Est. $\boldsymbol{\beta}$ & SE & RI \\
\hline CC & 0.13345 & 0.07960 & 1.00000 & 0.11492 & 0.07514 & 1.00000 \\
E & -0.00087 & 0.00034 & 0.85605 & -0.00083 & 0.00032 & 0.78870 \\
TD & -0.00002 & 0.00001 & 0.44373 & -0.00001 & 0.00001 & 0.37331 \\
TH & 0.02636 & 0.02691 & 0.37235 & 0.01814 & 0.02468 & 0.29726 \\
DBH & -0.00312 & 0.02669 & 0.25492 & -0.00350 & 0.02228 & 0.23728 \\
\hline
\end{tabular}

Tab. 3 - Summary of structural attributes and description of four stand types determined by cluster analysis of plots using mean tree cover, density, diameter at breast height (DBH), and height.

\begin{tabular}{ccrrrl}
\hline $\begin{array}{c}\text { Stand } \\
\text { type }\end{array}$ & $\begin{array}{c}\text { Average } \\
\text { Cover } \\
(\%)\end{array}$ & $\begin{array}{c}\text { Density } \\
\text { (trees } \\
\left.\text { ha }^{-1}\right)\end{array}$ & $\begin{array}{c}\text { DBH } \\
(\mathbf{c m})\end{array}$ & $\begin{array}{c}\text { Height } \\
(\mathbf{m})\end{array}$ & Description \\
\hline A & 85 & 2580 & 18.10 & 15.78 & High canopy cover, few large tall trees \\
B & 22 & 4898 & 4.60 & 3.60 & Low canopy cover, few small short trees \\
C & 42 & 2009 & 17.42 & 13.36 & Moderate canopy cover, few large tall trees \\
D & 78 & 28537 & 3.95 & 4.75 & High canopy cover, many small short trees \\
\hline
\end{tabular}


Tab. 4 - Association of a bird species with a particular stand type is indicated by $\left.1 .{ }^{*}\right)$ : $0.05<p \leq 0.10 ;(* *)$ : $\leq \leq 0.05$.

\begin{tabular}{|c|c|c|c|c|c|}
\hline \multirow{2}{*}{ Species } & \multicolumn{4}{|c|}{ Stand Type } & \multirow{2}{*}{ Prob. } \\
\hline & A & B & $\mathrm{C}$ & D & \\
\hline Buteo buteo & 1 & 0 & 0 & 0 & * \\
\hline Corvus corax & 0 & 0 & 0 & 1 & $* *$ \\
\hline Garrulus glandarius & 0 & 0 & 1 & 0 & * \\
\hline Phylloscopus collybita & 1 & 0 & 0 & 0 & * \\
\hline Sitta europaea & 1 & 0 & 0 & 1 & $* *$ \\
\hline Tachymarptis melba & 1 & 0 & 0 & 0 & * \\
\hline Turdus viscivorus & 1 & 0 & 0 & 0 & * \\
\hline
\end{tabular}

we observed 11 bird species, while the lower number of bird species (only 8) was observed in D stands. Three of them were observed only in D stands, whereas the others were also observed in A, B and C stands. In addition, in $A$ and $C$ stands 632 individuals (90\%) from 28 insectivorous bird species were recorded (Tab. S3 in Supplementary material).

According to multilevel pattern analysis, seven bird species were indicative species. B. buteo, P. collybita, T. melba and T. viscivorous were indicative species of stand type A, G. glandarius of stand type C, C. corax of stand type $D$, and $S$. europaea were indicative species of A and D stand types (Tab. 4, Tab. S4).

We found that widely distributed species pling.

\section{Variation in bird assemblage}

composition with stand structure

The stand structural variable that most were Fringilla coelebs, Parus major, Turdus merula, Dendrocopos medius, Picus canus and Lanius collurio, observed in three stand types (Tab. S4). These species were also highly abundant across our plots with 207 Fringilla coelebs, 80 Parus major and 64 Sitta europaea counted during the samstrongly influenced bird assemblage composition was canopy cover followed by tree density (Fig. 2). Tree DBH and height had relatively less impact on bird composition. Our indicative bird species Buteo buteo (BUTBUT), Corvus corax (CORCOR),

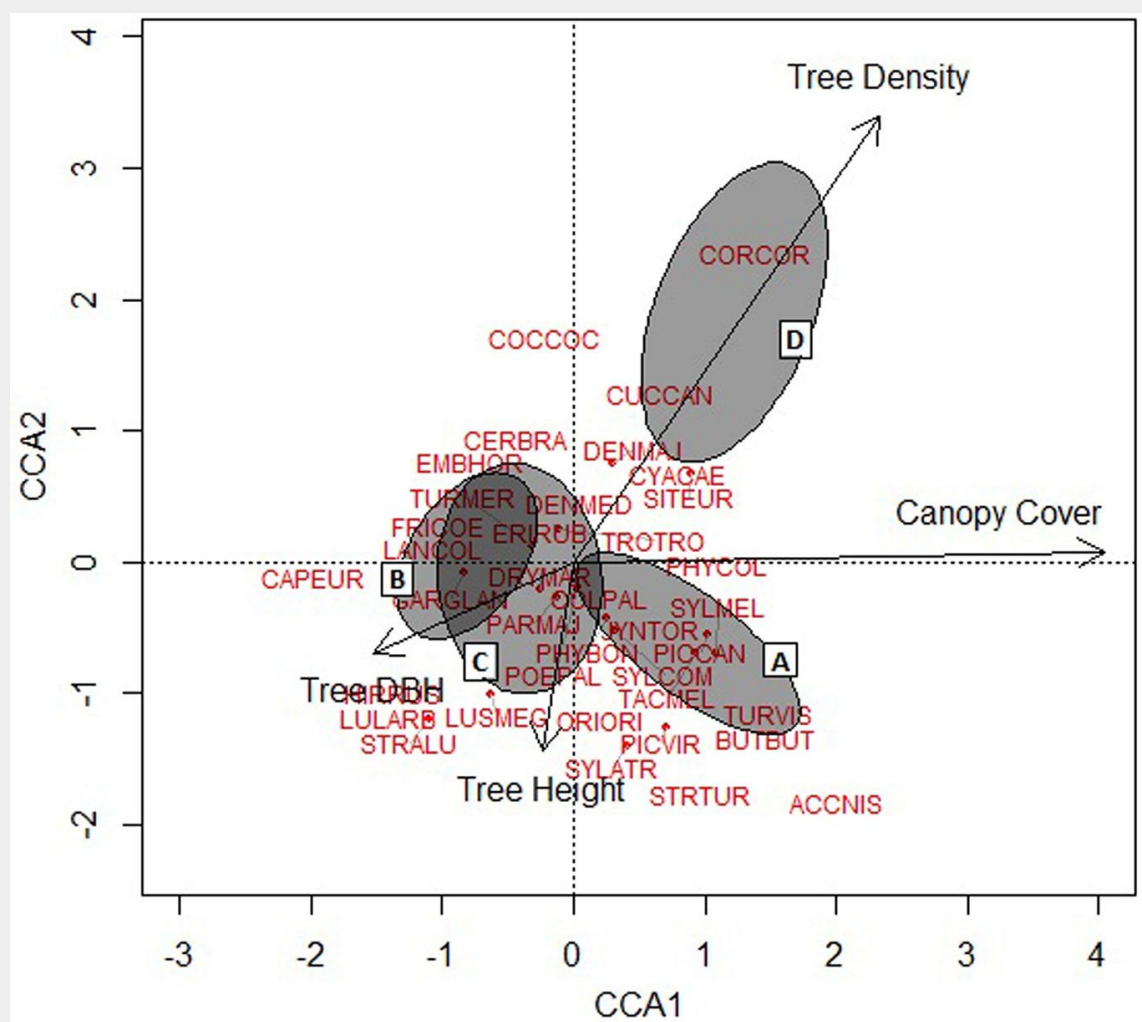

Fig. 2 - Bird species distribution in relation to individual stand structural attributes pro duced by Constrained Correspondence Analysis (CCA). The distribution of study sites on the ordination are shown by ellipses representing the $90 \%$ confidence interval boundary for each stand type (A, B, C, and D). The length and direction of the arrows indicate the relative influence of individual stand structural attributes on the composition of the bird community.
Sitta europaea (SITEUR), Phylloscopus collybita (PHYCOL), Tachymarptis melba (TAC$M E L$ ) and Turdus viscivorous (TURVIS) were positively affected by canopy cover and tree density, whereas Garrullus glandarius (GARGLA) was affected negatively by this variable, but positively by tree DBH. Picidae (woodpeckers) species were clustered in the center. Coccothraustes coccothraustes (COCCOC) and Cuculus canorus (CUCCAN) were strongly associated with tree density. In contrast, the species Caprimulgus europaeus (CAPEUR), Lullula arborea (LULARB), Hirundo rustica (HIRRUS), Strix aluco (STRALU) and Luscinia megarhynchos (LUSMEG) were associated with tree height (Fig. 2).

\section{Discussion}

Our findings demonstrate that stand structure, especially canopy cover, has a strong influence on bird species composition and diversity. The highest diversity of birds in our study area was found on stands that included tall trees and high canopy cover ( $\sim 42-85 \%$ corresponding to $\mathrm{A}$ and $\mathrm{C}$ stand types). Tree DBH, height, and vertical and horizontal stratifications influence bird diversity and abundance (Archaux \& Bakkaus 2007). Other vegetation characteristics, like maturity of trees or undergrowth density, may also play an important role in bird community dynamics (Diaz 2006), since the vegetative structure determines where and how species use resources (Block \& Brennan 1993). We found that canopy cover, height and DBH are all important for increasing and sustaining bird diversity. Large trees provide nesting habitat for many birds especially for resident species and cavity nesters (Jokimaki \& Solonen 2011). Keten et al. (2014) showed that insect diversity and abundance increased with tree $\mathrm{DBH}$ and tree height in coppiced Thracian oak forests. Thus, high insect abundance and diversity may be responsible for the greater bird diversity and numbers observed at tall and dense stands in our study. For example, of the seven species which showed significant associations with stand type, Sitta europaea, Phylloscopus collybita, Tachymarptis melba and Turdus viscivorous are insectivorous suggesting that insect abundance at these stands may be important for their distribution.

Winkler (2005) found that bird species richness, density and diversity in Sopron Mountains of Hungary were the lowest in the earliest successional stage and the highest in mature stands. In our study, early coppice stands (D stands) with a high number of stems $\left(\sim 30,000\right.$ trees ha $\left.{ }^{-1}\right)$ harbored very few bird species, most of which are generalists. The low number of bird species observed in short dense stands in our study might be due to the lack of a well developed understory shrub layer, as the development of the shrub layer is highly important for bird diversity and abundance (Camprodon \& Brotons 2006). B stands in 
our study represent low canopy cover with few small short trees. Bird species that prefer open forested habitat like Caprimulgus europaeus (Verstraeten et al. 2011), and intermediate pine forests like Streptopelia turtur (Bakaloudis et al. 2009) were the most seen bird species in these stands.

In contrast, species such as Phylloscopus collybita preferred stands with high canopy cover and tree density (A stands). Hinsley et al. (1996) also found $P$. collybita to be associated with mature trees and larger wood with dense canopy cover. $P$. collybita nests on the ground in the breeding season (Rodrigues \& Crick (1997) and may prefer the more abundant plant litter of mature stands with lack of disturbance.

Our findings further show that bird assemblage composition and the presence of specific bird species as well guilds are strongly associated with the developmental or successional stage of the vegetation. For example, predator species such as Accipiter nisus and Buteo buteo preferred high canopy cover and tall trees potentially because their preys (e.g., mice) are found in greater abundance in old oak stands (Keten et al. 2016). Many of the bird species in our study were only associated with a single stand type. For example, Erithacus rubecula, Corvus corax and Columba palumbus were only found at young coppice with short trees and high stem density. D stands represents dense $\left(28,537\right.$ trees ha $\left.^{-1}\right)$ but short trees (most $<1 \mathrm{~m}$ in height). E. rubecula breeds in hedgerows (Hinsley et al. 1995), while C. palumbus breeds in wood of all sizes (Hinsley et al. 1995). Thus D stands in our study may provide breeding habitat to these species, and feeding area for $C$. corax which feed and scavenge in open areas (Rösner et al. 2005).

Mistletoes are common in Thracian oak forests particularly where moderate canopy cover and large tall trees are found (Kumbasli et al. 2011). Cramp \& Perrins (1994) indicated that the most important birds for yellow mistletoe dispersal are Turdus viscivorus L. and Garrulus glandarius L., which were indicative species of stand $A$ and $C$ in our study. This suggests that these stands provide food for these bird species.

Among the most abundant species observed in our study were Turdus merula, Fringilla coelebs and Parus major, which are thought to be generalist. Our results show that these species can be found at A, B and $C$ stands but not in $D$ stands. Thus, these species show flexibility in habitat preference and only tend to avoid the earliest seral stages. Fuller \& Warren (1993) also found that T. merula, F. coelebs and P. major prefer older coppice forests.

While overall species diversity is favored by late succession stands with large tall trees, maintaining variation in canopy structure is crucial to increasing bird diversity across the landscape as a whole, given that different canopy stages hold importance for different bird species and guilds. MacColl et al. (2014) suggest that a mosaic of stand ages across the landscape is beneficial to a wide range of forest bird species and that management should consider the requirements of all age-classes of birds at different times of the year. Mullerova et al. (2015) measured the conservation value of forests based on the occurrence of red-list species, which were considerably reduced after coppice abandonment. Hence, as suggested by Mullerova et al. (2015), the re-establishment or maintenance of some areas under coppice management is crucial to prevent biodiversity loss.

\section{Conclusions}

Although we did not record any very rare or threatened bird species at our early seral stage stands, we suggest that continuing coppice management is beneficial for biodiversity conservation to some extent and that complete abandonment of coppicing and associated vegetation structure may result in local extinction or a decrease in abundance of some narrowly distributed and rare species in Turkey. While greater bird abundance may be observed in mature forests, maintaining young coppice stands may increase the overall landscape-scale bird diversity. Coppicing a limited proportion of the landscape does not hinder biodiversity conservation, as it is becoming clearer that the preservation of historical forms of management that molded forest composition may be crucial for the conservation of many rare species (Mairota et al. 2015).

\section{Acknowledgements}

This study was supported by The Scientific and Technological Research Council of Turkey (TUBITAK), Project Number: TOVAG-1070750. We thank Dr. Servet Caliskan, Dr. Hatice Yilmaz and Dr. Ohran Sevgi for their valuable contributions. This study was also supported by the Scientific Research Projects Coordination Unit of Istanbul University (Project number:UDP-34590)

\section{References}

Archaux F, Bakkaus N (2007). Relative impact of stand structure, tree composition and climate on mountain bird communities. Forest Ecology and Management 247 (1-3): 72-79. - doi: 10.1016/ j.foreco.2007.04.014

Bakaloudis DE, Vlachos CG, Chatzinikos E, Bontzorlos V, Papakosta M (2009). Breeding habitat preferences of the turtledove (Streptopelia turtur) in the Dadia-Soufli National Park and its implications for management. European Journal of Wildlife Research 55 (6): 597-602. - doi: 10.1007/s10344-009-0287-y

Barton K (2015). MuMIn: Multi-Model Inference (version 1.15.1). Web site. [online] URL: http:// cran.r-project.org/web/packages/MuMIn/MuM In.pdf

Bibby CJ, Burges ND, Hill DA (1992). Bird census techniques. Academic Press, San Diego, USA, pp. 257.

Block WM, Brennan LA (1993). The habitat concept in ornithology. Theory and application. In: "Current ornithology", vol. 11 (Power DM ed).
Plenum Press, New York, USA, pp. 35-91. Burnham KP, Anderson DR (2002). Model selection and multimodel inference: a practical information-theoretic approach. Springer, New York, USA, pp. 488. - doi: 10.1007/b97636

Calikoglu M, Kavgaci A (2002). Biyolojik Çesitliligin Sürekliligi ve Arttirilmasi Açisindan Baltaliklarin Koruya Dönüstürülmesi [Transformation of coppice lands to high forests in terms of continuity and enhancement of biodiversity]. Istanbul Üniversitesi, Orman Fakültesi, 51 (B2): 111121. [in Turkish]

Camprodon J, Brotons L (2006). Effects of undergrowth clearing on the bird communities of the Northwestern Mediterranean Coppice Holm oak forests. Forest Ecology and Management 221 (1-3): 72-82. - doi: 10.1016/j.foreco.20 05.10 .044

Colak A, Rotterham ID (2007). Classification of Turkish Forest by altitudinal zones to improve silvicultural practice: a case study of Turkish high mountain forests. International Forestry Review 9 (2): 641-652. - doi: 10.1505/ifor.9.2.641 Cramp SP, Perrins CM (1994). The birds of the Western Palearctic. Oxford University Press, Oxford, UK, pp. 488.

De Caceres M, Legendre P, Moretti M (2010). Improving indicator species analysis by combining groups of sites. Oikos 119 (10): 1674-1684. doi: 10.1111/j.1600-0706.2010.18334.x

De Warnaffe GD, Deconchat M (2008). Impact of four silvicultural systems on birds in the Belgian Ardenne: implications for biodiversity in plantation forests. Biodiversity and Conservation 17 (5): 1041-1055. - doi: 10.1007/s10531-008-9364-X DeGraaf RM, Hestbeck JB, Yamasaki M (1998). Associations between breeding bird abundance and stand structure in the White Mountains, New Hampshire and Maine, USA. Forest Ecology and Management 103 (2-3): 217-233. - doi: 10.1016/S0378-1127(97)00213-2

Diaz L (2006). Influences of forest type and forest structure on bird communities in oak and pine woodlands in Spain. Forest Ecology and Management 223 (1-3): 54-65. - doi: 10.1016/j.for eco.2005.10.061

Eraslan I, Evcimen BS (1967). Trakya'daki mese ormanlarinin hacim ve hasilati hakkinda tamamlayici arastirmalar [Complementary researches on volume and yield of oak forest in Thrace]. Istanbul Üniversitesi, Orman Fakültesi Dergisi, A 17 (1): 31-56 [in Turkish].

Fuller RJ, Stuttard P, Ray CM (1989). The distribution of breeding songbirds within mixed coppiced woodland in Kent, England, In relation to vegetation age and structure. Annales Zoologici Fennici 26 (3): 265-275. [online] URL: http://www.jstor.org/stable/23734593

Fuller RJ, Henderson ACB (1992). Distribution of breeding songbirds in Bradfield Woods, Suffolk, in relation to vegetation and coppice management. Bird Study 39 (2): 73-88. - doi: 10.1080 /00063659209477103

Fuller RJ, Warren WS (1993). Coppiced woodlands: their management for wildlife ( $2^{\text {nd }}$ edn). Nature Conservancy Council/HMSO, London, UK, pp. 29. [online] URL: http://jncc.defra.gov. uk/pdf/pubs93_Coppicedwoodlands.pdf Gregory RD, Van Strien A (2010). Wild bird indicators: using composite population trends of birds as measures of environmental health. 
Ornithological Science 9 (1): 3-22. - doi: 10.2326/ osj.9.3

Hartigan JA, Wong MA (1979). A K-means clustering algorithm. Applied Statistics 28: 100-108. - doi: $10.2307 / 2346830$

Hinsley SA, Bellamy PE, Newton I, Sparks TH (1995). Habitat and landscape factors influencing the presence of individual breeding bird species in woodland fragments. Journal of Avian Biology 26: 94-104. - doi: 10.2307/3677057 Hinsley SA, Bellamy PE, Newton I, Sparks TH (1996). Influences of population size and woodland area on bird species distributions in small woods. Oecologia 105: 100-106. - doi: 10.1007/BF 00328797

Jokimaki J, Solonen T (2011). Habitat associations of old forest bird species in managed boreal forests characterized by forest inventory data. Ornis Fennica 88 (2): 57-70. [online] URL: http://search.proquest.com/openview/2d e2b11b8416e66255fdod1d8a8d7e03/1

Keten A, Beskardes V, Kumbasli M, Makineci E, Zengin H, Ozdemir E, Yilmaz E, Cinar-Yilmaz H, Caliskan S, Anderson TJ (2014). Arthropod diversity in pure oak forests of coppice origin in northern Thrace (Turkey). iForest 8 (5): 615-623. - doi: 10.3832/ifor1318-007

Keten A, Beskardes V, Makineci E, Kumbasli M, Anderson TJ (2016). Abundance of Apodemus spp. varies by stand age in coppice-originated oak forest, Thrace, Turkey. Bosque 37 (2): 425429. - doi: 10.4067/S0717-92002016000200021 Kumbasli M, Keten A, Beskardes V, Makineci E, Ozdemir E, Yilmaz E, Zengin H, Sevgi O, CinarYilmaz H, Caliskan S (2011). Hosts and distribution of yellow mistletoe (Loranthus europaeus Jacq., Loranthaceae) on Northern Strandjas Oak Forests-Turkey. Scientific Research and Essays 6 (14): 2970-2975.

Legendre $P$, Legendre $L$ (2003). Numerical ecology ( $2^{\text {nd }}$ edn). Elsevier, Amsterdam, The Netherlands, pp. 1006. [online] URL: http://books. google.com/books?id=6ZBOA-iDviQC

MacArthur RH, MacArthur J (1961). On bird species diversity. Ecology 42: 594-598. - doi: 10.230 7/1932254

MacColl ADC, Feu CR, Wain SP (2014). Significant effects of season and bird age on use of coppice woodland by songbirds. Ibis 156 (3): 561575. - doi: 10.1111/ibi.12152

Magurran AE (1988). Ecological diversity and its measurement. Princeton University Press, Princeton, NJ, USA, pp. 179. [online] URL: http://books.google.com/books?id=CuUgDwAA QBAJ

Mairota P, Manetti Chiara M, Amorini E, Pelleri F, Terradura M, Frattegiani M, Savini $P$, Grohmann F, Mori P, Terzuolo PG, Piussi P (2015). Opportunities for coppice management at the landscape level: the Italian experience. iForest 9 (5): 775-782. - doi: 10.3832/ifor1865-009

Makineci E, Yilmaz E, Ozdemir E, Kumbasli $M$, Sevgi O, Keten A, Beskardes V, Zengin H, Yilmaz $\mathrm{H}$, Caliskan S (2011). Kuzey Trakya koruya tahvil mese ekosistemlerinde saglik durumu, biyokü- tle, karbon depolama ve faunistik özelliklerin belirlenmesi [Determination of health condition, biomass, carbon sequestration and faunistic characteristics on conversion of coppice oak ecosystems in Northern Thrace]. TÜBITAK Project, TUBITAK-TOVAG 1070750, Turkey, pp. 260. [in Turkish]

Mei-Ling B (2005). Tree cavity abundance and nest site selection of cavity nesting birds in a natural boreal forest of West Khentey, Mongolia. Doktorate thesis, Georg-August-Universität, Göttingen, Germany, pp. 175 [online] URL: http://www.deutsche-digitale-bibliothek.de/ binary/K6TU6EZKOPRPPZS77W5GEF4B7JJ4 $\mathrm{N}_{2} \mathrm{I}$ U/full/1.pdf

Moss D (1979). Even-aged plantations as a habitat for birds. In: "The Ecology of Even-aged Forest Plantations" (Ford ED, Malcolm DC, Atterson J eds). Institute of Terrestrial Ecology, Cambridge, UK, pp. 413-427. [online] URL: http:// nora.nerc.ac.uk/id/eprint/7078/1/No07078CP.pd

Mullerova J, Hedl R, Szabo P (2015). Coppice abandonment and its implications for species diversity in forest vegetation. Forest Ecology and Management 343: 88-100. - doi: 10.1016/j. forec0.2015.02.003

Mullerova J, Szabo P, Hedl R (2014). The rise and fall of traditional forest management in southern Moravia: a history of the past 700 years. Forest Ecology and Management 331: 104-115. doi: 10.1016/j.foreco.2014.07.032

OGM (2014). Türkiye Orman Varligi [Abundance of Forest in Turkey]. Pub. 115 (17), General Directorate of Forestry, Forest Management and Planning Department Publication, Turkey, pp. 36. [in Turkish]

Oksanen J, Blanchet $G$, Kindt R, Legendre $P$, Minchin PR, O'Hara RB (2015). vegan: community ecology package. Web site. [online] URL: http://cran.r-project.org/web/packages/vegan/ vegan.pdf

Paillet Y, Berges L, Hjalten J, Odor P, Avon C, Bernhardt-Romermann M, Bijlsma RJ, De Bruyn L, Fuhr M, Grandin U, Kanka R, Lundin L, Luque S, Maqura T, Matesanz S, Meszaros I, Sebastia MT, Schmidt W, Standovar T, Tothmeresz B, Uotila A, Valladares F, Vellak K, Virtanen R (2010). Biodiversity differences between managed and unmanaged forests: meta-analysis of species richness in Europe. Conservation Biology 24 (1): 101-112. - doi: 10.1111/j.1523-1739.2009. 01399. $\mathrm{x}$

Perrins C (1987). Vögel (Biologie + Bestimmen + Ökologie) [Birds-Biology, Description and Ecology]. Pareys Naturführer Plus, Hamburg und Berlin, Germany, pp. 320. [in German]

Pinheiro J, Bates D, DebRoy S, Sarkar D (2015). nlme: linear and nonlinear mixed effects models. R package version 3.1-131, pp. 336. [online] URL: http://cran.r-project.org/web/packages/nl me/nlme.pdf

R Development Core Team (2008). A language and environment for statistical computing. $\mathrm{R}$ Foundation for Statistical Computing, Vienna,
Austria. [online] URL: http://www.R-project.org Rackham O (2008). Ancient woodlands: modern threats. New Phytologist 180 (3): 571-586. - doi: 10.1111/j.1469-8137.2008.02579.x

Rodrigues M, Crick HQP (1997). The breeding biology of the Chiffchaff Phylloscopus collybita in Britain: a comparison of an intensive study with records of the BTO Reord Scheme. Bird Study 44 (3): 374-383. - doi: 10.1080/00063659 709461073

Rösner S, Selva N, Müller T (2005). Raven Corvus corax ecology in a primeval temperate forest. In: “Corvids of Poland”(Jerzak L, Kavanagh BP, Tryjanowski P eds). Bogucki Wyd. Nauk, Poznan, Poland, pp. 385-405. [online] URL: http:// www.zbs.bialowieza.pl/g2/pdf/1546.pdf

Sieferle RP (2001). The subterranean forest: energy systems and the industrial revolution. The White Horse Press, pp. 241.

Srámeki M, Volariki D, Ertas A, Matula R (2015). The effects of coppice management on the structure, tree growth and soil nutrients in temperate Turkey. Journal of Forest Science 61 (1): 27-34.

Svensson L, Mullarney K, Zetterström D (2009). Collins bird guide ( $2^{\text {nd }}$ edn). The most complete guide to the birds of Britain and Europe. Harpers Collins Ltd., Harper Collins, London, UK. pp. 400.

Venables WN, Ripley BD (2002). Modern applied statistics with S. Springer-Verlag, New York, USA, pp. 495.

Verstraeten G, Baeten L, Verheyen K (2011). Habitat preferences of European Nightjars Caprimulgus europaeus in forests on sandy soils. Bird Study 58 (2): 120-129. - doi: 10.1080/00063657. 2010.547562

Winkler D (2005). Ecological succession of breeding bird communities in deciduous and coniferous forest in the Sopron Mountains. Acta Silvatica et Lignaria Hungarica 1: 49-58. [online] URL: http://publicatio.nyme.hu/143/1/ winkler.pdf

\section{Supplementary Material}

Tab. S1 - Bird species observed across 50 sampling plots in Thracian oak forest stands and their respective feeding guilds.

Tab. S2 - The coefficients, AICc, $\triangle \mathrm{AIC}$, and model weight, for each of the top regression models predicting the influence of site factors on bird species richness and diversity.

Tab. S3 - Bird species observed across 50 sampling plots in Thracian oak forest stands stand type preferences.

Tab. S4 - Indicator value of the bird species recorded in the study based on multi-level pattern analysis.

Link: Beskardes_2489@supplo01.pdf 